\title{
AMERICAN CUTANEOUS LEISHMANIASIS OUTBREAK, TARTAGAL CITY, PROVINCE OF SALTA, ARGENTINA, 1993
}

\author{
O. Daniel SALOMON(1), Mario ZAIDENBERG(2), Ricardo BURGOS(2), Viviana I. HEREDIA(3) \& S. Liliana CAROPRESI(3)
}

\begin{abstract}
SUMMARY
An American cutaneous leishmaniasis outbreak, with cases clustering during 1993 in Tartagal city, Salta, was reported. The outbreak involved 102 individuals, $43.1 \%$ of them with multiple ulcers. Age (mean: 33 years old) and sex distribution of cases (74.5\% males), as well as working activity (70 forest-related), support the hypothesis of classical forest transmission leishmaniasis, despite the fact that the place of permanent residence was in periurban Tartagal. Moreover, during July, sandflies were only collected from one of the 'deforestation areas'. Lutzomyia intermedia was the single species of the 491 phlebotomines captured, reinforcing the vector incrimination of this species. Most infections must have been acquired during the fall (April to June), a pattern consistent with previous sandfly population dynamics data. Based on the epidemiological and entomological results, it was advised not to do any vector-targeted periurban control measures during July. Further studies should be done to assess if the high rate of multiple lesions was due to parasite factors or to infective vector density factors.
\end{abstract}

KEYWORDS: Leishmaniasis; Lutzomyia intermedia; Argentina.

\section{INTRODUCTION}

Human leishmaniasis cases are estimated to be around 12 million worldwide from 88 countries, with 2,000,000 estimated new cases every year. However, only 600,000 are officially reported ${ }^{6,21,22}$.

American mucocutaneous leishmaniasis has been endemic in the northern provinces of Argentina, with human cases known since 1917 ${ }^{10,20}$. Reporting of leishmaniasis is mandatory (Law 15465), and the national records up to the 80 's indicated that the average number of cases usually ranged from 40 to 90 per year, distributed in nine provinces ${ }^{2,3}$.

The disease was usually diagnosed in isolated cases, mostly adult males employed in forest-related work. However, an outbreak due to Leishmania (Viannia) braziliensis took place in the province of Salta, Argentina, from 1984 to 1987, involving periurban areas, with similar incidence in males and females as well as within the youngest ${ }^{15,16,19}$. The annual incidence rose from 6.4/100,000 inhabitants in 1984 to 28.7/ 100,000 in 1985 . After the outbreak, the trend was a decrease towards endemic rates until 1993, when a sudden new increase in human cases was reported from the San Martín and Orán Departments, close to Pichanal village, the former 1984 focus (Table 1).

Tartagal, one of the most affected areas during the 1993 outbreak, is the third city in importance of the province of Salta with 51,250 inhabitants. Therefore, the 'urban' leishmaniasis transmission hypothesis rose from different areas related to the health system. Moreover, most of the cases were reported clustering inside the city perimeter or in the periphery neighborhoods. Thus, a characterization of the focus during the outbreak was performed in order to evaluate the leishmaniasis urbanization hypothesis, and to propose rational control measures. This study presents the diagnosis and the epidemiological and entomological descriptive results of the 1993 field study.

Table 1

American Cutaneous Leishmaniasis incidence rate $(1 / 100,000)$ in the three departments of the province of Salta with the highest proportion of cases, and for the whole province of Salta, Argentina, from 1990 to 1997

\begin{tabular}{lcrrc}
\hline Year & San Martín & Orán & Anta & Province \\
\hline 1990 & 16.2 & 82.9 & 7.7 & 13.0 \\
1991 & 23.0 & 7.8 & 20.2 & 4.9 \\
1992 & 25.4 & 25.0 & 7.5 & 6.6 \\
1993 & 89.6 & 24.4 & 0.0 & 14.0 \\
1994 & 24.2 & 26.5 & 7.3 & 6.8 \\
1995 & 11.1 & 18.8 & 2.4 & 10.5 \\
1996 & ND & ND & ND & 14.4 \\
1997 & 72.0 & 128.6 & 19.2 & 25.3 \\
\hline
\end{tabular}

ND: Not discriminated 


\section{MATERIAL AND METHODS}

Diagnosis-Clinical data - The diagnosis was performed by local teams in three ways: a) clinically, b) parasitologically, by the smear of the ulcers and histopathologic samples observation, and c) immunologically, by the Montenegro Skin Intradermic Reaction (MSIR), as explained elsewhere ${ }^{17}$.

Epidemiological data - The official files of 102 cases were analyzed. The accuracy of the results varies according to the studied variable. Thus, a physical examination and a non-structured questionnaire was performed to almost all cases when they came spontaneously to the health system facilities or by domiciliary visits.

Entomological data - Sandfly captures were performed with a modified Shannon trap with human protected bait, and a CDC minilight trap settled $200 \mathrm{~m}$ from the former ${ }^{13}$. Insects were collected from 7 PM to 9 PM during July (winter) and kept in PBS with DMSFO 10\% under liquid nitrogen until they were dissected and observed under a contrast phase microscope searching for parasites. In domiciles and peridomiciles visited during the day a search of sandflies was made at probable rest sites.

Statistical analyses - The analyses of proportions were performed by the $\chi^{2}$ test or by the Fisher exact two-tailed test. All statistical tests were regarded as significant with associated probabilities $<0.01$ (CI 95\%).

\section{RESULTS}

Diagnosis-Clinical aspects - Leishmaniasis cutaneous lesions were present in 93 out of 102 reported cases. It was a single ulcer in $48.1 \%$ of the individuals and multiple in $43.1 \%$ of them, while the muco-cutaneous form accounted for the $8.8 \%$ remaining cases. The single ulcer localization is shown in Table 2. Most of the ulcers (77.5\%) were typical, with elevated borders and granular red bottom, few were scabs or healing lesions in the longer lasted cases. Among the people with multiple ulcers, the average was 2.5 ulcers/case ( 1 to 5 ) with the main localization in limbs, close to the primary lesion. The muco-cutaneous wounds were present in 8 cases in the nasal cartilage and in the remainder one in the uvula, all of them with more than 60 days of evolution and without any previous cutaneous antecedent.

Parasites Leishmania-like were observed in smears from 88/88 cases, and in the whole histopathological slides studied $(n=16)$. The MSIR was reactive in 77/77 cases with an induration average of $32 \mathrm{~mm}$ among the recorded cases $(n=16)$.

Epidemiological aspects - Cutaneous leishmaniasis was diagnosed in 102 individuals from 1 to 72 years old (yo) (mean 33 yo, mode 18 yo) (Table 3). Male cases (74.5\%) were significantly higher than female ones $(25.5 \%)$. However, cases in the age group from 1 to 10 years old were significantly higher for females $(8 / 18)$ than for males $(5 / 71)$. According to the case recalling, the ulcer had had less than 2 months of evolution in $59.1 \%$ of the cases $(n=102)$ (Table 4$)$. Taking into account the previous data, discriminated by week, the seasonal pattern of leishmaniasis incidence during the outbreak showed a significant peak around July, with $53.8 \%$ of the cases between July and August (Table 5). The incidence distribution by place of residence is shown in Table 6 , with the main concentration in Tartagal city. The place of infection was pointed out as the rural or periurban area close to the work or living place in $97.7 \%$ of the cases $(n=87)$, although none of the cases could recognize the vector, so this answer may have a strong bias. Discriminating the cases by occupation, almost $70 \%(n=43)$ of the people had performed some kind of forest-related work in the first half of 1993 (e.g. deforestation, mud brick making, burning of vegetal coal), while the rest were half farmers and half housekeepers or youngsters.

Entomological aspects - Phlebotomine captures were intended close to the houses with cases at Misión San Benito, Puesto Yapura, periurban Tartagal, and Ballivián, but no sandflies were collected. However, 488 sandflies were obtained with a Shannon modified trap during a temperate night $\left(19^{\circ} \mathrm{C}-22^{\circ} \mathrm{C}\right)$, from $7 \mathrm{PM}$ to $9 \mathrm{PM}$ at the deforesters' dwellings (Río Seco, close to Sauzalito), $22 \mathrm{~km}$ from Ballivián village. The sex ratio (females to males) was $3: 1$. All sandflies belonged to the species Lutzomyia intermedia, and none of the females had natural Leishmania infections. Only 3 sandflies $L u$. intermedia were collected by the CDC light trap in the same place during the same period.

Table 2

Leishmaniasis single ulcer localization, Tartagal outbreak, Salta, Argentina, 1993

\begin{tabular}{lcc}
\hline Localization & Cases & $(\%)$ \\
\hline Legs & 19 & 38.8 \\
Arms & 17 & 34.7 \\
Trunk & 7 & 14.3 \\
Head & 6 & 12.3 \\
\hline TOTAL & 49 & 100.0 \\
\hline
\end{tabular}

Table 3

American Cutaneous Leishmaniasis cases by age and sex, Tartagal outbreak, Salta, Argentina, 1993.

\begin{tabular}{lrrrrrr}
\hline \multirow{2}{*}{ Age } & \multicolumn{2}{c}{ Male } & \multicolumn{2}{c}{ Female } & \multicolumn{2}{c}{ TOTAL } \\
\cline { 2 - 7 } & $\mathrm{N}$ & $\%$ & $\mathrm{~N}$ & $\%$ & $\mathrm{~N}$ & $\%$ \\
\hline $1-10$ & 5 & 6.6 & 8 & 30.8 & 13 & 12.74 \\
$11-20$ & 12 & 15.9 & 5 & 19.2 & 17 & 16.66 \\
$21-30$ & 15 & 19.7 & 4 & 15.4 & 19 & 18.62 \\
$31-40$ & 12 & 15.8 & 6 & 23.1 & 18 & 17.64 \\
$41-50$ & 10 & 13.2 & 2 & 7.7 & 12 & 11.76 \\
$51-60$ & 13 & 17.1 & 1 & 3.8 & 14 & 13.72 \\
$\geq 61$ & 9 & 11.8 & 0 & 0.0 & 9 & 8.82 \\
\hline TOTAL & 76 & 100.0 & 26 & 100.0 & 102 & 100.0 \\
\hline
\end{tabular}

Table 4

Evolution time (in days) of the Leishmaniasis primary ulcer by case recalling, Tartagal outbreak, Salta, Argentina, 1993

\begin{tabular}{ccc}
\hline Time in days & Cases & $\%$ \\
\hline $0-30$ & 34 & 33.3 \\
$31-60$ & 26 & 25.8 \\
$61-90$ & 15 & 14.7 \\
$91-180$ & 10 & 9.8 \\
$\geq 181$ & 17 & 16.7 \\
\hline TOTAL & 102 & 100.0 \\
\hline
\end{tabular}


Table 5

Monthly pattern of American Cutaneous Leishmaniasis incidence by case recalling, Tartagal outbreak, Salta, Argentina, 1993

\begin{tabular}{lcc}
\hline Month & Cases & $\%$ \\
\hline January & 2 & 2.1 \\
February & 5 & 5.4 \\
March & 1 & 1.1 \\
April & 8 & 8.6 \\
May & 5 & 5.4 \\
June & 9 & 9.7 \\
July & 31 & 33.3 \\
August & 19 & 20.4 \\
September & 0 & 0.0 \\
October & 2 & 2.1 \\
November & 6 & 6.5 \\
December & 5 & 5.4 \\
\hline TOTAL & 93 & 100.0 \\
\hline
\end{tabular}

Table 6

American Cutaneous Leishmaniasis cases and incidence rate $(1 / 100,000)$ by place of residence (county). Tartagal outbreak, Salta, Argentina, 1993

\begin{tabular}{ccc}
\hline Locality & Cases & Incidence \\
\hline Tartagal & 61 & 132.7 \\
Orán & 15 & 28.05 \\
Gral.Mosconi - Gral. Ballivián & 6 & 51.4 \\
H. Irigoyen & 5 & 56.0 \\
Col Santa Rosa & 4 & 12.1 \\
Embarcación & 4 & 29.0 \\
Pichanal & 3 & 26.1 \\
Aguaray & 1 & 14.6 \\
San Martín del Tabacal & 1 & 85.4 \\
Cnel. Cornejo & 1 & 63.5 \\
\hline TOTAL & 101 & \\
\hline
\end{tabular}

Capture efforts were also made at the three sites where the local population pointed out urban/periurban transmission, although no phlebotomine was found: 1) Peridomiciliary environments on the Tartagal river shore within a Ricinus secondary forest (2 houses). 2) The Tartagal city garbage land. 3) Possible resting sites inside and around each case domicile. In the first two places, Shannon modified traps and CDC mini light traps were settled and an active search was made inside the houses, including the collection of insects' fragments from spider webs.

\section{DISCUSSION}

An outbreak of American Cutaneous Leishmaniasis took place in 1993 around Tartagal city, San Martín Department, province of Salta, Argentina. The proportion of cases with multiple lesions (43.1\%) was significantly higher than the figures previously reported for the area $(10.3 \%)^{17}$, without any association with the time of ulcer evolution. The "multiple ulcer" phenomena may be due to multiple infective bites, as it happens in contact with "hot spots" (high-density of vector and reservoirs) scattered within the residual forest, or may be due to parasite virulence factors related to a different Leishmania species or strain variant of $L$. $(V$.) braziliensis, the species characterized in the study area. Mucocutaneous ulcers without any previous cutaneous antecedent may be due also with the amount of infective bites and cutaneous contiguity or with parasite strain virulence. Further studies and parasite isolation should be done to support any of these hypotheses. On the other hand, the high percentage of positive smears was probably related with the diagnosis methodology used by the local health system, who takes the smears twice if the case has a leishmaniasis-like ulcer and a first negative smear, thus improving the sensitivity of the method. The ulcer localization previously reported was $71.8 \%$ in $\operatorname{limbs}^{17}$, while it was $73.5 \%$ in this outbreak. Moreover, in both studies, the main localization was in legs. Thus, the same vector species may be involved from 1984 to 1993.

The sex ratio among cases with male predominance $(74.5 \%)$, and the age mean and mode during work-active ages are usually associated in the literature with forest-work related transmission ${ }^{8}$. On the other hand, the sex related risk was neutralized or reversed within the lower age groups. This result could be explained by two facts: 1) The families of people involved in deforestation and/or immediate farmering are settled in residual primary forest patches, called "curtains"; this exposition may be responsible for female and youngest infection of leishmaniasis as it is for Hantavirus (Sosa Estani, pers. comm.). 2) Some activities that facilitate infective contacts with vectors in the forest, as the search of fire-wood and water, are gender related with young females. However, these hypotheses should be tested by specific studies.

The ulcer evolution time was less than 60 days for $60 \%$ of the cases as it was reported by case recalling. Thus, as most of the cases had clinical symptoms in July, and the incubation period was about 5 to 6 weeks ${ }^{18}$, it is likely that the transmission took place before the winter lowest temperatures. This fact was consistent with the sandfly population dynamics model proposed for the area, as the model estimated the highest human risk during the fall ${ }^{13}$.

After the 80's outbreak, five phlebotomine species were cited for the Orán-San Martín area ${ }^{14}$ : Lutzomyia (Nyssomyia) intermedia (Lutz and Neiva, 1912); Lutzomyia migonei (França, 1920); Lutzomyia cortelezzii (Brèthes, 1923); Lutzomyia (Psathyromyia) punctigeniculata Floch and Abonnenc, 1944; and Lutzomyia (P.) shannoni (Dyar, 1929). Lutzomyia intermedia was the most prevalent species captured in all traps, representing between 80 and $90 \%$ of the captures. Interestingly, the previous publications on peridomestic sandflies from this area did not record $\mathrm{Lu}$. intermedia ${ }^{1,7}$, which is currently the most abundant species. Lutzomyia intermedia has been found naturally infected with $L$. (V.) braziliensis in Brazil ${ }^{9,11}$. It is highly prevalent in peridomestic habitats in Brazil and Paraguay ${ }^{4}$, where it avidly seeks humans to feed on ${ }^{5,12}$. The lack of phlebotomine collections in the periurban area did not mean that these insects could not reach those peridomiciliary environments. Actually, during the 1993 captures, the temperature was close to the lower limit for Lutzomyia intermedia's activity (SALOMON, 1997). However, this species was collected in temperate microhabitats, at primary forests near highly modified new farming fields, which could explain the species abundance. Moreover, many cases of people who have been working close to the capture area (Ballivián, Km 6) support the hypothesis that the infection could have been acquired there.

In conclusion, the 1993 Leishmaniasis outbreak in Salta seems to have the traditional forest-related transmission pattern. At least it seems to be the main component, despite the place of residence of the cases. Further studies are required to assess the virulence of the strain or the higher 


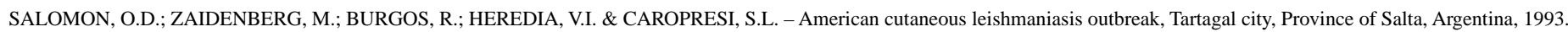
Rev. Inst. Med. trop. S. Paulo, 43(2): 105-108, 2001.

infective bite rate in this situation. Lutzomyia intermedia is again suspected to be the primary vector of leishmaniasis in the area. The collection of phlebotomines during a temperate night of winter, in forest protected microenvironments, brings new data to the seasonal population dynamics studies (overwintered adults), and it has implications both for transmission understanding and control designs (target on population with highest reproduction potential). Although the periurban transmission could be important in some scenarios as the Salta 80 's outbreak ${ }^{17}$, the forest remains as the main site where the infection takes place, or as an outbreak "seed", further amplified by periurban transmission. This fact is essential to keep in mind when: 1) domiciliary antivectorial measures are required by the community despite the fact that during the winter no sandfly reaches the domestic habitats, and 2) the area is under a broad schedule of deforestation. After the reported outbreak, from 1997 up to now, the leishmaniasis morbidity rose in the Orán and San Martín Departments. Although this new outbreak is under current research, the work hypothesis is that the cases are mainly related with focalized deforestations.

\section{RESUMO}

\section{Surto de leishmaniose cutânea americana na cidade de Tartagal, Província de Salta, Argentina, 1993}

Foi registrado um surto de leishmaniose cutânea americana, com casos agrupados na cidade de Tartagal, província de Salta, durante 1993. O surto envolveu 102 indivíduos, 43,1\% deles com úlceras múltiplas. A idade (média: 33 anos) e distribuição de sexo nos casos (74,5\% homens) como também a ocupação (70\% relacionado com a floresta), apóia a hipótese da clássica transmissão de leishmaniose na floresta, apesar do fato de que o lugar de residência permanente estava na área periurbana de Tartagal. Além disso, durante julho, foram colecionados flebótomos só de uma área de desmatamento. Lutzomyia intermedia foi a única espécie dos 491 flebotomíneos capturados e reforça a incriminação de vetor desta espécie. A maioria das infecções deve ter sido adquirida durante o outono (abril para junho), um padrão consistente com dados prévios sob a dinâmica de população de flebótomos. Com base nos resultados, epidemiológicos e entomológicos foi aconselhado não fazer qualquer controle sobre vetores na área periurbana durante julho. Mais adiante deveriam ser feitos estudos para avaliar se a alta taxa de lesões múltiplas foi devido a fatores do parasita ou a fatores de densidade do vetor.

\section{ACKNOWLEDGMENTS}

We want to thank Dr. Elsa L. Segura, Director of ANLIS, and the team of the CeNDIE for their tireless collaboration, specially Dr. Sosa Estani. This work was possible with the support of the Federal Ministry of Health (Epidemiology), and the Ministry of Public Health of the province of Salta (Dir Epidemiology, EDIS). We want to thank also the staff of the Hospital, the Primary Health Care agents and supervisors, and the community of Tartagal.

\section{REFERENCES}

1. BEJARANO, J.F.R. \& DURET, J.P. - Contribución al conocimiento de los flebótomos Argentinos (Diptera, Psychodidae). Rev. Sanid. milit. Argent., 49: 327-336, 1950.

2. BERNASCONI, V.E. - Consideraciones sobre el censo de leishmaniosis. Rev. Soc. Pat. Reg. Norte, 5: 590-602, 1930.
3. CEDILLOS, R.A. \& WALTON, B.C. - Leishmaniasis: special situations in other Areas of the Americas. In: Research on Control Strategies for the Leishmaniasis. IDRC CDDI CIID, Report 184e: 156-161, 1988.

4. HASHIGUCHI, Y.; CHILLER, T.; INCHAUSTI, A. et al. - Phlebotomine sandfly species in Paraguay and their infection with Leishmania. Ann. trop. Med. Parasit., 86: 175$180,1992$.

5. LAINSON, R. - Demographic changes and their influence on the epidemiology of the American leishmaniases. In: SERVICE, M.W., ed. Demography and vector-borne diseases. Boca Raton, CRC Press, 1989. p. 85-106.

6. MARINKELLE, C.J. - The control of leishmaniases. Bull. Wld. Hlth. Org., 58: $807-$ 818,1980 .

7. MAZZA, S. - Consideraciones sobre flebótomos encontrados en Tabacal y el papel de estos dípteros en la transmisión de Leishmaniosis. Bol. Inst. Clin. quir. (B. Aires), 2: $310-317,1926$.

8. MOTT, K.E.; DESJEUX, P.; MONCAYO, A.; RANQUE, P. \& RAADT, P. - Parasitic diseases and urban development. Bull. Wld. Hlth. Org., 68: 691-698, 1990.

9. PEREIRA, I.R. \& HOCH, A. - Lutzomyia intermedia as a suspected vector of Leishmania viannia braziliensis in Bahia State, Brazil. Rev. Soc. bras. Med. trop., 23: 235, 1990.

10. QUINTANA, H. \& ETCHEVERRY, J.B. - Leishmaniosis Americana en la Provincia de Jujuy. Cong. Nac. Medicina (B. Aires), 1(2): 847-860, 1917.

11. RANGEL, E.F.; SOUZA, N.A.; WERMELINGER, E.D. \& BARBOSA, A.F. - Infecção natural de Lutzomyia intermedia Lutz \& Neiva, 1912, em área endemica de leishmaniose tegumentar no estado do Rio de Janeiro. Mem. Inst. Oswaldo Cruz, 79: 395-396, 1984.

12. RANGEL, E.F.; SOUZA, N.A.; WERMELINGER, E.D. et al. - Flebótomos de Vargem Grande, foco de leishmaniose tegumentar no estado do Rio de Janeiro. Mem. Inst. Oswaldo Cruz, 81: 347-349, 1986.

13. SALOMON, O.D. - Phlebotomine sandflies at a Leishmaniasis focus in Argentina. New Haven, 1997. (Ms. Thesis - Yale University)

14. SALOMON, O.D.; TRAVI, B.L. \& SEGURA, E.L. - Note on sandflies associated with a tegumentary leishmaniasis focus in Salta, Argentina, 1988. Rev. Inst. Med. trop. S. Paulo, 37: 91-92, 1995.

15. SOSA ESTANI, S.; SALOMON, O.D.; GOMEZ, A. \& SEGURA, E.L.- Prevalencia de leishmaniasis en Salta, Argentina. Medicina (B. Aires), 53(supl.1): 78, 1993.

16. SOSA ESTANI, S.; GOMEZ, A.; SALOMON, O.D. \& SEGURA, E.L. - Leishmaniasis en Argentina. Factores de riesgo. Rev. Soc. bras. Med. trop., 27(supl.1): 243, 1994

17. SOSA ESTANI, S.; CAMPANINI, A.; SINAGRA, A. et al. - Características clínicas y diagnóstico de la Leishmaniasis mucocutanea en pacientes de un área endémica de Salta. Medicina (B. Aires), 58: 685-691, 1998.

18. SOSA ESTANI, A. - Prevalencia de infección y factores de riesgo de la transmisión de leishmaniasis en Salta, República Argentina. Buenos Aires, 1999. (Ph.D. Thesis - Buenos Aires University).

19. VILLAFAÑE, R.; RICHTER, E.E. \& SOAVE DE RICHTER, L. - Análisis crítico de la epidemia de leishmaniasis, años: 1985/87. Salta, Ministerio de Salud Pública, Dirección General de Epidemiología, 1988.

20. VILLALONGA, J.F. - Leishmaniosis tegumentaria americana: clínica y tratamiento. Rev. Fac. Med. Tucumán, 6: 197-208, 1963.

21. WALSH, J.F.; MOLYNEUX, D.H. \& BIRLEY, M.H. - Deforestation: effects on vectorborne disease. Parasitology, 106(suppl.): S55-S75. 1993.

22. WHO - Control of the Leishmaniases. Wld. HIth. Org. techn. Rep. Ser., (793), 1990.

Received: 31 January 2000

Accepted: 30 October 2000. 